ks. Mariusz Piecyk

\title{
Urząd duchowny w dialogu Kościoła rzymskokatolickiego z Kościołem ewangelicko-reformowanym
}

\section{THE OFFICE OF PRIEST IN THE DIALOGUE BETWEEN THE ROMAN CATHOLIC CHURCH AND THE EVANGELICAL-REFORMED CHURCH}

In this article, which deals with the office of ministry in the Roman Catholic Church's dialogue with the Evangelical Reformed Church, the author states that the Church is based in her activities on the mission of Jesus as well as on the power of the Holy Spirit and living the faith of the first apostles she preserves her apostolic nature. The analysis of dialogue documents shows that the common priesthood of the baptized does not mean that there are no special features which, within the Church, are exercised by the representatives of a particular office, entrusted with the ministry of Word and sacrament. It was stressed that the liturgical validity of the act of ordination provides the epiclesis of the Holy Spirit during the laying on of hands on the newly ordained by a group of clergy. The Catholics and Reformed point to difficult issues such as apostolic succession, although their views on its significance remain divergent. It is highlighted that the fundamental structure of the Church and ecclesial authority are collective in nature, which in the Reformed tradition is reflected in the synodal system of church government and in the Roman-Catholic confession is fulfilled in the College of Bishops. The both denominations have also confirmed the existence of the fundamental structure of the office of bishop, priest and deacon, having its origins in apostolic times. The Catholics and Reformed emphasize the need of episkopé on the local, regional and global levels 
and at the same time they note some differences regarding who, on each of these levels, can be considered as episkopos and what his function is to be. It is also pointed out that according to the doctrine of the Catholic Church, each ordained acts in persona Christi, and his office consists of the ministry of the sent who acts on behalf of the Saviour in the service of the Word of God..

Teologia dialogu

Key words: office of priest, common priesthood, apostolic succession, bishop, Catholics, reformed.

Kościoły reformowane, prezbiteriańskie i kongregacjonalne, tworzą rodzinę Kościołów wywodzących się ze szwajcarskiego nurtu Reformacji XVI wieku U. Zwingliego oraz J. Kalwina. Mimo ważnej roli genewskiego Reformatora teologia reformowana nigdy nie stanowiła monolitu związanego z jednym ośrodkiem i jedną konfesją, jak choćby to miało miejsce w przypadku luteranizmu. Jednak we wszystkich Kościołach reformowanych są żywe, obecne i konsekwentnie przestrzegane podstawowe reguły Reformacji: sola gratia, sola fide, sola Scriptura oraz soli Deo gloria, a także Ecclesia reformata semper reformanda. Powyższe zasady warunkują naukę, organizację i życie całej społeczności, aczkolwiek żadna z reformowanych wspólnot nie traktuje swej konfesji jako zamkniętej i raz na zawsze zakończonej. W ujęciu reformowanej teologii Kościół rozumiany jest jako wspólnota wybranych, powołanych i gromadzonych przez Jezusa Chrystusa. Kościół jest obecny wszędzie tam, gdzie wierzący spotykają się z Bogiem przez Słowo i sakramenty. Głową i Panem Kościoła jest Odkupiciel, będący zarazem jedynym pośrednikiem między Bogiem i ludźmi. To przez Niego wierzący otrzymują zbawienie z łaski przez wiarę, przy czym wiara stanowi tu jedynie środek pozwalający przyjąć łaskę usprawiedliwienia. W związku z tym w Kościele reformowanym nie istnieje stan kapłański, nie ma tu miejsca dla kultu oraz uznawane są tylko dwa sakramenty: chrzest i Wieczerza Pańska. Należy nadto zauważyć, że u reformowanych istotą sakramentu jest działanie w nim i przez niego Ducha Świętego; jest on rozumiany jako widzialny i święty znak, który został ustanowiony przez Chrystusa dla potwierdzenia obietnicy zbawienia. Owe eklezjologiczne założenia oraz znacząca elastyczność doktryny i działania spowodowały, że Kościół reformowany przyjmuje otwartą postawę wobec innych wyznań, stając się niemal od samego początku motorem ekumenicznych dążeń ${ }^{1}$.

J.Stahl, Kościoły i wspólnoty kościelne tradycjizachodniej. Kościoły reformowane, [w:] W. Hryniewicz, J. S. Gajek. S. J. Koza (red.), Ku chrześcijaństwu jutra. Wprowadzenie do ekumenizmu, Lublin 1997, s. 171, 174-176. Por. także:K. Karski, 


\section{Pierwsza faza dialogu reformowanych z katolikami}

Decyzja o podjęciu bilateralnego dialogu zapadła w 1968 roku zarówno po stronie Sekretariatu ds. Jedności Chrześcijan, jak i Komitetu Wykonawczego Światowego Aliansu Kościołów Reformowanych. Rok później powołano specjalną Komisję Studiów, która za przedmiot badań przyjęła temat: „Obecność Chrystusa w Kościele i świecie”. Owocem pierwszej fazy rozmów, obejmującej lata 1970-1977, stał się dokument Obecność Chrystusa $w$ Kościele $i$ świecie, poruszający następujące kwestie: stosunek Jezusa do Kościoła, autorytet nauczający w Kościele, obecność Chrystusa w świecie, Eucharystię i urząd kościelny ${ }^{2}$.

Wprowadzając w zagadnienie urzędu kościelnego przywołany wyżej dokument stwierdza, że Kościół opiera swe życie i działalność na posłannictwie Jezusa, nakazującym mu wyjście do świata, a także na misji Ducha Świętego, który włącza mężczyzn i kobiety do służby sprawowanej przez Chrystusa. Autorytet Kościoła związany jest nierozdzielnie z jego posługiwaniem w świecie, który stanowi przedmiot stwórczej i pojednawczej miłości Boga. Duchowni, będąc sługami służącego Pana, mają obowiązek posługi na rzecz świata w sposób mądry i cierpliwy w myśl zasady, że gdzie nie ma autentycznie żywego naśladowania Odkupiciela, tam również nie może być mowy o wiarygodnym sprawowaniu eklezjalnego urzędu. Sprawujący posługiwanie w Kościele muszą więc zawierzyć zapewnieniu Chrystusa, iż Jego postanowieniem jest budowanie wspólnoty nawet przy pomocy niedoskonałych sług. Dlatego też katolicy i reformowani podjęli wspólne wysiłki w celu głębszego zrozumienia istoty kościelnego urzędu, motywowanego troską o służbę Kościoła w świecie ${ }^{3}$.

W ujęciu dialogowego dokumentu katolicko-reformowanego Kościół ma charakter apostolski, co oznacza bycie posłanym i posiadanie szczególnego posłannictwa. W podjętym dialogu pojęcie ,posłannictwa" ma zasadnicze znaczenie dla zrozumienia kościelnego urzędu. I tak: jak Ojciec posłał Chrystusa, tak również Kościół zostaje przez

Symbolika.Zarys wiedzyo Kościołach i wspólnotach chrześcijańskich, Warszawa 2003, s. 169-170.

2 Por. S. Napiórkowski, Topografia dialogów międzywyznaniowych, [w:] W. Hryniewicz, J. S. Gajek. S. J. Koza (red.), Ku chrześcijaństwu jutra. Wprowadzenie do ekumenizmu, Lublin 1997, s. 529-530; K. Karski, Od Edynburga do Porto Alegre. Sto lat dążń ekumenicznych, Warszawa 2007, s. 255.

3 Dokumente wachsender Übereinstimmung. Sämtliche Berichte und Konsenstexte interkonfessioneller Gespräche auf Weltebene, Bd 1, 1931-1982, Paderborn 1983 (odtąd: DwÜ I), n. 93, s. 510. 
Teologia dialogu

Jezusa posłany. Przy czym misja Kościoła nie posiada jedynie wymiaru chrystologicznego, bowiem apostolstwo Chrystusa i przysposobienie Kościoła do służby są także dziełem Ducha Świętego, którego moc jest nie tylko konieczna dla jego skutecznego funkcjonowania i eklezjalnego urzędu, lecz jest ich organicznym elementem, bez którego ani Kościól, ani urząd duchowny nie mogą istnieć. Można więc powiedzieć, że istniejące „wynaturzenia” w teologicznym ujęciu urzędu stanowią zbyt często rezultat i oznakę niedopracowanej teologii trynitarnej. To właśnie moc Ducha jest tym, czym Pan podtrzymuje swój Kościół w jego apostolskim powołaniu, a co przejawia się w różny sposób w charyzmatach, czyli szczególnych darach Ducha Świętego (por. 1 Kor 12, 4). Stąd też Kościół zyskuje charyzmatyczny wymiar nawet wtedy, kiedy staje się narzędziem realizacji Bożego planu w świecie ${ }^{4}$.

Kościół posiada przeto apostolskie znamię, ponieważ żyje wiarą pierwszych Apostołów, kontynuując powierzoną im przez Zbawiciela misję oraz kiedy trwa w służbie i sposobie życia, czemu oni wcześniej dawali świadectwo. Normatywny wymiar owej apostolskości stanowią objawione pisma kanoniczne. Dlatego w Nowym Testamencie, w którym najpełniej dochodzi do głosu ów normatywny wyraz apostolskości, można odnaleźć świadectwo potwierdzające szczególny urząd, który Jezus powierzył Dwunastu, a w ramach tej wspólnoty - Piotrowi ${ }^{5}$.

Dokument dialogowy podkreśla nadto, iż urząd Chrystusa, w tym również Jego urząd kapłański, rozciąga się na wszystkich członków Jego ciała (por. 1 P 2, 5-9), bowiem każdy ochrzczony na swój sposób wnosi nowy akcent do owego ogólnego urzędu posługiwania, posiadając udział w powszechnym kapłaństwie wierzących. Owo powołanie do kapłaństwa wszystkich, którzy poprzez sakrament chrztu stają się

Tamże, n. 94, s. 510-511. Nie ulega najmniejszej wątpliwości, że Kościół Chrystusowy i urząd duchowny stanowią zarówno rzeczywistość chrystologiczną, jak i pneumatologiczną. Według Yvesa Congara dotychczasowa eklezjologia przesadnie akcentowała aspekt instytucjonalny, stając się niejako „hierarchiologią”. Przedstawiała Kościół jako religijną instytucję, umożliwiającą zbawienie i ustanowioną w oparciu o powołanie Apostołów przez Chrystusa, postawienie Piotra na ich czele i wyposażenie w jurysdykcyjną władzę oraz przez święcenia. Nie ukazywano jednak w wystarczającym stopniu, w przeciwieństwie do teologii Kościoła Wschodniego, działania Ducha Świętego. Tymczasem wszelka zbawcza i uświęcająca aktywność Kościoła, w której ordynowane posługiwanie spełnia tak istotną rolę narzędziową, dokonuje się w mocy Ducha. Trzeba więc podkreślić, iż Chrystus w swoim Kościele jest obecny i działa nade wszystko przez Ducha Świętego. Por. W. Miziołek, Urzad a charyzmat. Hierarchiczna i charyzmatyczna struktura Kościoła, „Ateneum Kapłańskie” 80(1973)384, s. $82-83$.

5 DwÜ I, n. 95, s. 511. 
uczestnikami Jezusowego ciała, nie oznacza jednak, że nie istnieją specjalne funkcje, które w ramach Kościoła spełniają przedstawiciele szczególnego urzędu ${ }^{6}$.

Powiedzieć bowiem trzeba, iż w ramach ogólnie rozumianej apostolskości istnieje szczególny urząd, któremu powierzono posługę Słowa i sakramentu. Posługiwanie to będąc jednym z charyzmatów, spełnia wyjątkową rolę w odniesieniu do całego ciała ${ }^{7}$. Przy czym ordynacja bądź wyznaczenie do pełnienia owego urzędu odbywa się zawsze dialogu przy udziale wspólnoty wierzących, gdyż ordynacyjna procedura przewiduje konsultację ze wszystkimi wiernymi danej gminy, wyznanie wiary złożone w jej obecności oraz partycypację w liturgicznym akcie święceń. Podkreślenie wyżej wskazanych elementów pozostaje także ważne i z tego powodu, ponieważ konieczne jest wyzwolenie się z takiego pojmowania ordynacji, które sugerowałoby, jakoby kandydat przeznaczony na urząd duchowny mógł zyskać władzę (potestas) i godność od samego Chrystusa bez łączności ze wspólnotą wierzących ${ }^{8}$.

\footnotetext{
Tamże, n. 96, s. 511.
}

Trzeba jasno powiedzieć, iż zarówno urząd, jak i charyzmat nie są przeciwieństwami, lecz zawsze pozostają na siebie zdane i ukierunkowane, istniejąc razem w jednym Kościele. Władza eklezjalnego autorytetu stanowi rzeczywistość posiadaną i pełnioną niejako przez członka Kościoła, co niemożliwe się staje chcąc ją wykonywać na zewnątrz naprzeciwko wspólnoty. Urząd i charyzmat są więc funkcjami ochrzczonych w Kościele, który sami tworzą. W przypadku osoby pełniącej posługę lub obdarzonej charyzmatem, o kwestii bliskości człowieka do Boga decyduje ostatecznie pełne łaski wezwanie Stwórcy, a po stronie człowieka miara jego poświęcenia w miłości i gotowości służenia drugim. Odnośnie zaś znaczenia urzędu i charyzmatu dla Kościoła orazjego pośrednictwa w zbawieniu nie można powiedzieć, że działania podmiotu owego urzędu mogłyby posiadać w każdym razie większą moc zbawczą. Zdaniem K. Rahnera, historycznie kreatywne impulsy Ducha kierowane do Jego Kościoła bardzo często nie pochodzą od urzędu eklezjalnego, lecz posłane zostają do tegoż urzędu przez charyzmatyków w imię zasady, że Duch tchnie, kędy chce. Stąd wydaje się oczywistym fakt, że charyzmat nie może być administrowany przez posiadającego urząd, ponieważ nie stanowi on reprezentanta Jezusa w taki sposób, że Duch Święty mógłby działać li tylko w jego duszy i rozwijać swą sprawczość w Kościele. Należy zatem powiedzieć, iż urząd nie jest panem Ducha i Jego charyzmatów, lecz ich sługą. Nosicielowi kościelnego autorytetu nie przysługuje zatem kompetencja rozstrzygania, czy w konkretnym przypadku ma do czynienia z charyzmatem i w jakim zakresie ów dar może w Kościele funkcjonować, bowiem zgodnie z nauką Pisma Świętego istnieje oddzielny charyzmat rozróżniania duchów, który winien w tym miejscu zadziałać. Charyzmatyk z kolei powinien wiedzieć, że kierowniczy urząd Kościoła stanowi dar Ducha dany Kościołowi i dlatego musi uważać, ażeby wobec urzędu swój charyzmat uwierzy telnić. Por. A. Skowronek, Z Kościołem $w$ trzecie tysiaclecie, Włocławek 1999, s. 57-58.

DwÜ I, n. 97, s. 511. 
Liturgiczna prawomocność aktu ordynacji przewiduje epiklezę Ducha Świętego podczas nakładania rąk na wyświęcanego przez grupę ordynujących duchownych. To przyzywanie Parakleta ma przypomnieć, iż w każdym obiektywnym pojmowaniu urzędu fundamentalną rolę winna pełnić doktryna o Trójcy Świętej. W ten sposób postępując, dowartościowuje się przeszłe i teraźniejsze czyny Jezusa oraz stałe działanie Ducha. Nałożenie rąk stanowi więc skuteczny znak, który wprowadza ochrzczonego w powierzony mu urząd, jednocześnie w nim go utwierdzając. Przy czym tworzenie i autoryzacja owego autorytetu nie leży w gestii wspólnoty, bowiem Tym, który obdarza gminę eklezjalnym posługiwaniem i włącza go w jej życie, jest żywy Chrystus ${ }^{9}$.

Integralną częścią wymiaru suwerennej i łaskawej obecności Chrystusa, w którego przekazywaniu pośredniczy Kościół, jest ciągłość szczególnej służby w dziedzinie Słowa i sakramentu. Odpuszczenie grzechów oraz wzywanie do pokuty stanowi sprawowanie władzy kluczy w życiu koinonii, którą Jezus powierzył Apostołom, zapewniając zarazem, że będzie nieustannie obecny aż do skończenia świata. Owa apostolska ciągłość jest nie tylko związana z pierwotnym nakazem Zbawiciela, lecz również z kontynuowanymi przez Niego przesłaniami i działaniami ${ }^{10}$.

W ten sposób dokument dialogowy dochodzi do pojęcia ,sukcesji apostolskiej", któremu na przestrzeni wieków nadawano różne znaczenia. Używając tego słowa w jego najbardziej lapidarnym znaczeniu, które nawiązuje do ciągłości szczególnego urzędu eklezjalnego, zauważyć trzeba, iż zawiera się ono bez wątpienia w ramach apostolskości, będącej przymiotem całego Kościoła. Katolicy i reformowani wierzą, że istnieje apostolska sukcesja, która posiada zasadnicze znaczenie dla życia Wspólnoty, choć ich poglądy odnośnie sensu jej roli pozostają rozbieżne. Zgodzono się jednak co do tego, że nikt nie przejmuje szczególnego urzędu posługiwania jedynie z własnej inicjatywy, ale że do owej służby w dziedzinie Słowa i sakramentu, posługi charakteryzującej

9 Tamże, n. 98, s. 511. Pneumatologiczny obrzęd nałożenia rąk i modlitwy odnosi się do nieprzerwanego łańcucha kościelnej tradycji, który wyraża więź zachodzącą między chrystologią a pneumatologią, a zarazem daje wyraz powszechnemu wymiarowi eklezjologii. Należy zauważyć, iż nieprzerwane działanie Ducha Świętego i niepowtarzalne wydarzenie Wcielenia pozostają wewnętrznie ze sobą powiązane: Duch stanowi najwyższy Dar, którego wywyższony Jezus udziela tym, którzy od początku z Nim byli (por. J 15, 26-27), oraz tym, którzy spełniają jakąś posługę w Jego Kościele (por. Ef 4, 8-12). Posłanie Ducha przynosi więc ludziom wszystkich czasów zbawcze dzieło Chrystusa, jednakże nigdy go nie zastępuje. Por. J. Ratzinger, Formalne zasady chrześcijaństwa. Szkice do teologii fundamentalnej, Poznań 2009, s. 331. 
się ciągłością, wstępuje się na mocy powołania przez wspólnotę oraz na mocy aktu święceń dokonywanych przez innych duchownych ${ }^{11}$.

Z obustronnych ustaleń wynika, że sukcesja apostolska istnieje przynajmniej w dziedzinie ciągłości apostolskiej nauki. Ponadto dokument stwierdza, iż nie ma sprzeczności pomiędzy ową kontynuacją a sukcesją dotyczącą nieprzerwanego przekazywania duchownego urzędu. Jako gwaranta ciągłości właściwej nauki wymienia się Pismo Święte, przy czym przekazicielem pozostaje eklezjalny urząd w swej Teologia nauczającej roli. Apostolska sukcesja, podobnie zresztą jak wszystkie inne aspekty kościelnego posługiwania, wymaga historycznej kontynuacji idąc za pierwszymi Apostołami, przy zachowaniu równoczesnego, łaskawego i ożywiającego działania Ducha Świętego. Bowiem zgodnie z obietnicą Odkupiciela, Kościół żyje z mocy Pocieszyciela obdarzającego go nieustannie i dobrowolnie swoimi darami. Wszystko to zdaje się wykluczać rytualistyczną koncepcję sukcesji, mechaniczne pojmowanie ciągłości oraz sukcesję oderwaną od historycznej wspólnoty chrześcijańskiej ${ }^{12}$.

Katolicy i reformowani wyrazili nadto obopólną zgodę, iż fundamentalna struktura Kościoła i eklezjalnego urzędu posiada charakter

$11 \quad$ DwÜ I, n. 100, s. 512.

12 Tamże, n. 101, s. 512. Warto zauważyć, iż zdaniem kard. J. Ratzingera, nałożenie rąk, połączone z modlitwą do Ducha Świętego nie stanowi jakiegoś odizolowanego od Kościoła rytu, dzięki któremu można niejako wykopać swego rodzaju „prywatny kanał” do Apostołów, pomijając Kościół powszechny, ale jest raczej wyrazem kontynuacji Kościoła, który w biskupim kolegium stanowi przestrzeń dla przekazywania Ewangelii. Według katolickiej teologii, akcent zostaje położony na nieprzerwanej identyczności Tradycji, która jest utrzymywana w sposób nienaruszony w communio konkretnego Kościoła i która urzeczywistnia się w eklezjalnym geście nałożenia rąk. Dlatego nie może istnieć jakiekolwiek rozdzielenie materialnego i formalnego aspektu (następstwo w słowie, następstwo w nałożeniu rąk), lecz ich wewnętrzna jedność stanowi znak jedności samego Kościoła: nakładanie rąk odbywa się w Kościele i dzięki niemu żyje, a bez niego pozostaje bez wartości. Nałożenie rąk, niebędące samo w sobie wejściem w relację z życiem i Tradycją Kościoła, nie może być nazwane kościelnym nałożeniem rąk. Sakrament jest bowiem sakramentem Kościoła, a nie prywatną drogą wiodącą ku początkom. Dlatego też problem, który w tym miejscu pojawia się pomiędzy Kościołem katolickim i rodziną protestanckich wspólnot, zdaje się dotyczyć nie tyle zagadnienia sakramentu i sakramentalności, ale sięga na wskroś do Pisma Świętego i Tradycji. Sakrament nałożenia rąk, będąc sakramentem Kościoła, stanowi równocześnie wyraz struktury kościelnej Tradycji. Łączy ze sobą katolickość i apostolskość, adekwatnie do jedności Jezusa i Ducha Świętego, która to jedność urzeczywistnia się i w sposób dogłębny dokonuje w eucharystycznej wspólnocie. Por. J.Ratzinger, Nauka Kościołao,,sacramentum ordinis”, [w:] Kapłaństwo (kolekcja Communio), Poznań - Warszawa 1988, s. 72-73. 
Teologia dialogu

kolegialny. Ordynowana osoba akceptuje dyscyplinę związaną z pełnieniem kolegialnej funkcji, która wymaga poddania się innym oraz korzystania ze wsparcia i napomnień innych kolegów w duchownym urzędzie. „Kolegialność” ta w tradycji reformowanej znajduje swój wyraz w synodalnej organizacji, z kolei w wyznaniu rzymskokatolickim urzeczywistnia się w kolegium biskupów, którego rozumienie uległo dalszej ewolucji. U reformowanych synod spełnia rolę zbiorowego episkopatu, który sprawuje nadzór nad duchownymi i parafiami. Podczas dialogowych dyskusji zauważono jednocześnie konieczność bliższego zastanowienia się nad sposobem nadania rozmaitym funkcjom związanym z reformowanym urzędem starszych współczesnej formy i korzystnego wykorzystania tych funkcji w życiu Kościoła. Wyrażono natomiast zgodę co do kwestii, że kolegialna struktura, zależnie od epoki, musi być wyrażana w inny sposób, co każe zwiększyć wrażliwość na różnorodność charyzmatów. Zasada kolegialności nie powinna bowiem ograniczać się li tylko do płaszczyzny synodów, a w Kościele katolickim do poziomu kolegium biskupów bądź duchownych, lecz winna być stosowana na wszystkich poziomach kościelnego życia. Zasugerowano więc w tym wypadku przydatność koncepcji wyrażonej pod pojęciem sobornost ${ }^{13}$.

Dialogujące strony zwracają także uwagę na istnienie odnośnie urzędu odmiennych teologicznych poglądów, które nie mieszczą się $\mathrm{w}$ ramach danej tradycji wyznaniowej, gdyż w obu wyznaniach ma się do czynienia $\mathrm{z}$ różnorodnym rozłożeniem akcentów, które wbrew powszechnemu przekonaniu, wychodzą poza ustalone granice konfesyjne. Niektórzy podkreślają np. ostre przeciwieństwo zachodzące pomiędzy Duchem a strukturą, inni natomiast bezwzględnie akcentują rolę Ducha w tworzeniu i ożywaniu struktur ${ }^{14}$. Przedstawiciele jednego poglądu bardziej lub mniej ubolewają wskutek faktu, iż sukcesja apostolska została zredukowana wyłącznie do podtrzymywania tradycji nakładania rąk, podczas gdy zwolennicy innej teorii wyrażają mniejsze bądź większe zadowolenie z powodu takiej właśnie instytucjonalizacji

13 DwÜ I, n. 102, s. 512-513.

14 „Manche sehen in der Anwendung der Analogie der Inkarnation auf die Ekklesiologie eine Unterschätzung des Wirkens des Geistes und der Herrschaft Christi über die Kirche. Andere denken, dass die Analogie der Inkarnation mit Recht auf die Kirche angewandt werden kann, wenn dies in einem trinitarischen Kontext erfolgt, welcher der Dynamik des Wirkens Christi durch den Heiligen Geist gerecht wird. Dies kann bedeuten, dass ein Konvergenzpunkt darin besteht, dass niemand von der Kirche als einer «Verlängerung der Inkarnation» sprechen möchte, dass aber zugleich eine wahre Divergenz in bezug auf die Art und Weise besteht, eine von der Inkarnation geprägte Sprache in der Lehre über die Kirche zu verwenden". DwÜ I, n. 104, s. 513. 
sukcesji apostolskiej, dostrzegając w niej nowy przykład, wypływającej z miłości obecności Chrystusa. Z kolei jeszcze inni jako przestrzeń apostolskiej ciągłości wymieniają jedynie sukcesję apostolskiego zwiastowania, ale są również i tacy, którzy widzą ową kontynuację w nieprzerwanej sukcesji, czego zasadniczym elementem jest również nałożenie rąk ${ }^{15}$.

Występujące między katolikami i reformowanymi różnice w doktrynie o urzędzie wynikają często nie z obiektywnie różnych koncepcji, ale daleko bardziej z różnic w mentalności, prowadzących do odmiennego akcentowania elementów będących częścią jednej wspólnej tradycji. Doktrynalne rozbieżności zdają się jednak decydować o tym, że rzymskokatolickie spojrzenie na posługiwanie duchowne różni się od stanowiska reformowanego, co najczęściej było wyrazem zaistnienia czynników kulturowych, socjologicznych i ekonomicznych czy też niuansów życia duchowego. Trzeba jednak zauważyć, że obydwa teologiczne ujęcia w szczególny sposób zdają sobie sprawę z tego, jak istotne znaczenie dla realizacji powierzonego zadania mają kościelne struktury. Kościół katolicki wyprowadza swój ustrój eklezjalny z władzy Jezusa, posiadając w przeważającej mierze hierarchiczny charakter. Kościół reformowany z kolei, powołując się na ten sam Chrystusowy autorytet, zdecydował się wprowadzić kościelną organizację, która $\mathrm{w}$ dominującym stopniu posiada prezbiterialno-synodalny wymiar. Stąd z punktu widzenia ekumenicznego zaangażowania wydaje się być konieczne przestudiowanie na nowo tych elementów Kościoła, które przeważały w pierwszym okresie jego egzystencji ${ }^{16}$.

Istotnym problemem jest podchodzenie przez każdą z tradycji w odmienny sposób do stopnia i sposobu istnienia wspólnoty wierzących oraz jej komunii z Jezusem, a w szczególności celebracji Eucharystii, domagającej się obecności w Kościele ordynowanego duchownego. Pojawia się również pytanie, w jakiej mierze prawidłowa nominacja na urząd w Kościele wymaga instytucjonalnej koherencji z urzędem Piotrowym i z posługą biskupa? Dla katolików łączność z biskupem Rzymu posiada decydujące znaczenie w przeżywaniu katolickości. Z kolei reformowani przeżywają ją w sposób najbardziej bezpośredni przez partycypowanie w konkretnej wspólnocie lokalnej. Odnośnie natomiast relacji pomiędzy urzędem a sakramentem, katolicy odnoszą wrażenie, że reformowani nie doceniają rozmiaru, w jakim Bóg w swoim planie zbawczym związał się z Kościołem, urzędem i sakramentem. Reformowani zaś uważają, że teologia katolicka zbyt często

15 DwÜ I, n. 103, s. 513.

16 Tamże, n. 105-106, s. 513-514. 
nie docenia sposobu, w jaki Kościół, urząd i sakramenty pozostają w relacji do wolności i łaski Ducha Świętego ${ }^{17}$.

\section{Druga faza bilateralnego dialogu}

W 1984 roku rozpoczęto drugą fazę doktrynalnych rozmów, która zakończyła się opublikowaniem dokumentu $K u$ wspólnemu rozumieniu Kościoła (1990). Z punktu widzenia niniejszej rozprawy istotny pozostaje rozdział trzeci, który podejmuje zagadnienie relacji między Ewangelią a Kościołem w ich służebnej i instrumentalnej funkcji, czyniąc to w oparciu o takie tematy, jak: Kościół będący creatura verbi a Kościół jako sakrament łaski, kontynuacja i dyskontynuacja w dziejach Kościoła, czy kwestia struktury Kościoła i porządku urzędu posługi. Z kolei w czwartym rozdziale naszkicowano pewne drogi wiodące w przyszłość, gdzie zajęto się pokrótce kwestią małżeństw mieszanych ${ }^{18}$.

Odnośnie misji i struktury urzędów, katolicy i reformowani są zgodni, iż ustrój Kościoła ma swój początek w Ewangelii, którą Zmartwychwstały Pan nakazał zwiastować swoim uczniom. Mając na uwadze tę perspektywę, został on dany w pierwszym rzędzie w Słowie i sakramencie: „Idźcie więc i czyńcie uczniów wśród wszystkich narodów, chrzcząc ich w imię Ojca i Syna, i Ducha Świętego. Uczcie ich zachowywać wszystko, co wam nakazałem. A oto Ja jestem z wami przez wszystkie dni aż do końca świata" (Mt 28, 19-20; por. Łk 24, 4748; J 20, 21b). Misja, którą Chrystus powierzył jedenastu Apostołom (por. Mt 28, 16) i z której wyrósł Kościół, oznacza konieczność wprowadzenia rozróżnienia między tymi, którzy zwiastują Ewangelię, a tymi, którym jest ona zwiastowana. Pociąga więc to za sobą posługę Słowa, sakramentu i nadzoru, którą powierzył Kościołowi Odkupiciel, by była sprawowana przez niektórych jego członków dla dobra całej wspólnoty. Owa trojaka funkcja posługi wyposaża Kościół pełniący swoje posłannictwo w świecie. Porządek zaś posługiwania manifestuje się zwłaszcza w posłudze Słowa, czyli w głoszeniu Ewangelii (por. 1 Tes 2, 13; 2 Kor 11, 7), zapowiedzi pokuty i przebaczania grzechów w imieniu Chrystusa (por. Łk 24, 47-48) oraz w zwiastowaniu Tego, którego namaścił Duch Pański, aby „zwiastował ubogim Dobrą Nowinę”, a „wziętych do niewoli wypuścił na wolność" (Łk 4, 18). W ten sposób Chrystus, będący zwiastunem Słowa Bożego, stał się par excellence Tym, którego

17 DwÜ I, n. 107, s. 514.

18 Por. K. Karski, Od Edynburga do Porto Alegre..., dz. cyt., s. 255. 
zwiastowano w Słowie, a wybrani przez Niego świadkowie (por. Dz 10, 41-42) zanieśli je aż po krańce ziemi ( $\mathrm{Dz} 1,8)^{19}$.

Porządek posługi znajduje również swój wyraz w sakramentach, w których - zgodnie z wiarą - działa Chrystus przez Ducha Świętego pośród swego ludu. Zwłaszcza chrzest i Eucharystia wspólnie ze Słowem Bożym stanowią dla wierzących skuteczne środki łaski, przez które buduje się i karmi cały Lud Boży. Oprócz tego ów porządek manifestuje się w posłudze nadzoru (episkopé), która ze względu na wierność, jedność, harmonię, wzrost oraz dyscyplinę pielgrzymującego Kościoła, jest sprawowana przez jego członków pod przewodnictwem Chrystusa jako prawdziwego Pasterza i Stróża (episkopos) wszystkich dusz (por. $1 \mathrm{P} 2$, 25). I chociaż różnorodne dary łaski, posługi i sposoby działania powstają w Kościele wskutek inspiracji Ducha Świętego (por. 1 Kor 12, 4-6), to jednak wszyscy członkowie wezwani są do otaczania troską tej samej jedności, harmonii i integralności Kościoła ${ }^{20}$.

Trzeba powiedzieć, że przywództwo w Nowym Testamencie, w różnych okresach i miejscach przyjmowało rozmaite określenia i formy (por. Dz 1, 20-25; 20, 17; 28; 1 Kor 12, 28; Ef 4, 11-13; Flp 1, 1; 1 Tm 3, 1-13; 4, 14; 5, 3-22; Tt 1, 5-9). I tak, św. Paweł określał siebie jako sługę Jezusa Chrystusa (zob. Rz 1, 1; Ga 1, 10; Flp 1, 1), pisząc w tym charakterze do założonych przez siebie wspólnot, powołując się na autorytet przysługujący mu na podstawie Ewangelii, którą głosił (zob. 1 Tes $2,9.13 ; 1$ Kor 15, 11). I choć nie istnieje bezpośredni dowód, że zbory, które założył Apostoł Narodów, były zorganizowane w sposób prezbiterialny, to jednak są wzmianki, według których wyznaczał on w każdym z nich starszych (Dz 14, 23), a już na pewno zdawał sobie sprawę, że w niektórych gminach istniała kierownicza struktura (por. 1 Tes 5, 12; Flp 1, 1). Z tych przeto rozmaitych modeli kierowniczych, o których wspominają listy pasterskie, narodziła się fundamentalna struktura: biskup, prezbiter i diakon, co do końca II wieku zdobyło sobie właściwe uznanie ${ }^{21}$.

$19 \quad$ Dokumente wachsender Übereinstimmung. Sämtliche Berichte und Konsenstexte interkonfessioneller Gespräche auf Weltebene, Bd 2, 1982-1990, Paderborn 1992 (odtąd: DwÜ II), n. 130, 132-133, s. 661-662.

20 Tamże, n. 134-135, s. 662.

21 Tamże, n. 136, s. 662. „Diese Leitungsstruktur hat sich aus einigen neutestamentlichen Formen entwickelt, während andere (sogar ältere) neutestamentliche Formen sich nicht entfalteten. Die Ausbreitung und theologische Interpretation kirchlicher Leitung in der unmittelbaren nach-neutestamentlichen Zeit muss auf dem Hintergrund der umfassenderen Entwicklung der frühen Kirche und ihrer Artikulation des Glaubens gesehen werden. Im Laufe der Geschichte veränderten sich einige der Funktionen solcher Leiter; dennoch 
Teologia dialogu

Trzeba jednak zaznaczyć, iż pomimo przedstawionych poglądów na temat sakramentów i duchownego urzędu w Kościele, co do których osiągnięto konsens, istnieją również różnice wymagające dalszych studiów. I chociaż jest faktem wzrastające zbliżenie w dziedzinie sakramentów, to jednak nadal istnieje niezgodność nie tylko co do ich liczby, lecz także rozbieżność w definiowaniu ,sakramentu” i pełnomocnictwa tego, który jest jego szafarzem. Zgodnie z orzeczeniami Soboru Trydenckiego ${ }^{22}$, katolicy uznają siedem sakramentów, chociaż sakramentowi chrztu i Eucharystii zdają się przypisywać większe znaczenie, aniżeli pozostałym oraz uznają w Eucharystii źródło i szczyt sakramentalnego życia Kościoła. Kościoły reformowane traktują chrzest i Wieczerzę Pańską jako sakramenty we właściwym znaczeniu, aczkolwiek w nałożeniu rąk dostrzegają skuteczny znak, wprowadzający wierzącego w powierzany mu urząd i w tym urzędzie utwierdzający. Reformowani w tym miejscu powołują się na Kalwina, który nie sprzeciwiał się nazywaniu ordynacji sakramentem, choć nie sytuował jej na tej samej płaszczyźnie z sakramentami chrześcijańskiej inicjacji ${ }^{23}$.

Już w poprzednim dokumencie (Obecność Chrystusa w Kościele $i$ świecie) zarysowano opis ordynacji, ukazując jej podwójne odniesienie do przeszłych i obecnych czynów Chrystusa oraz do stałego działania Ducha Świętego. Tutaj warto zasygnalizować fakt, iż nadal

wurde das Amt der Bischöfe, Presbyter und Diakone in der Alten Kirche das universale Modell der Kirchenleitung”. DwÜ II, n. 137, s. 662-663. Biskupi są zwłaszcza nadzorcami społeczności, ustanowionymi po to, by czuwać nad poszczególnymi gminami. W początkowej fazie tymi, którzy trzymali pieczę, byli prezbiterzy, czyli starsi, obecni zazwyczaj w każdej gminie. Listy pasterskie poświadczają jednak, że w każdej wspólnocie był tylko jeden biskup, którego winno się wybierać z największą starannością $(1 \mathrm{Tm} 3,1-7)$ i według wszelkiego prawdopodobieństwa spośród starszych (Tt 1, 5-9). Wysłannicy Pawła, Tytus i Tymoteusz, posiadają władzę nad starszymi, diakonami i biskupami Kościołów, które zostały im powierzone. Są zwłaszcza odpowiedzialni za gminę w zakresie liturgii (1 Tm 1, 1-15) i przekazywania nauki (1 Tm 4, 6. 13-16; 6, 3). Ów fakt swoistego delegowania władzy rządzenia, która kiedyś była zarezerwowana dla samych Apostołów, stanowi dowód, że organizacja Kościoła podlegała pewnej ewolucji. Kiedy więc już ich zabrakło, struktura ta ustaliła się w postaci trzech hierarchicznych stopni: biskupów, będących pasterzami i przełożonymi społeczności, wspieranych przez nich prezbiterów, a którym z kolei pomagali diakoni. Specjalna łaska, niezbędna do pełnienia poszczególnych funkcji, była przekazywana, identycznie jak za czasów apostolskich, przez włożenie rąk (por. 2 Tym 1, 6). Por. P. Grelot, Postuga, [w:] X. Leon-Dufour (red.), Stownik teologii biblijnej, Poznań 1994, s. 727.

Por. DS 1601. 
istnieją trudności odnośnie istoty święceń. Postawiono więc ważne pytanie: czy wraz z nałożeniem rąk wiąże się misyjne pełnomocnictwo, przekazanie władzy lub też włączenie do stanu duchownego? $\mathrm{Z}$ drugiej strony, rodzi się pytanie: czy defekt pod względem formy może poddać w wątpliwość urząd czy nawet go unieważnić, oraz czy można go uzdrowić poprzez łączność z wiarą Kościoła? Na pewno dalsza rozbieżność w tej kwestii nie może być odłożona ad acta! Ponadto należy także zauważyć ważny problem istnienia w Kościołach dialogu reformowanych coraz powszechniejszej praktyki ordynowania kobiet, którym nie nakłada się żadnych ograniczeń w zakresie pełnienia posługi Słowa i sakramentu ${ }^{24}$.

Kolejnym zagadnieniem jest sprawowanie autorytetu Chrystusa w Kościele, wobec którego występuje obopólna zgoda co do kolegialnego charakteru struktury urzędu oraz konieczności istnienia episkopé zarówno na płaszczyźnie lokalnej, regionalnej czy światowej. Przy czym dostrzega się pomiędzy katolikami i reformowanymi różnice odnośnie tego, kto na tych różnych szczeblach może być uznany jako biskup i na czym winna polegać jego funkcja lub rola. I tak, katolicy akcentują, że urząd z mocy ordynacji stanowi Boży dar, udzielany we wspólnocie powołanym do tego osobom (por. Rz 1,1). Przez sakrament święceń duchowny jednoczy się z Chrystusem, jedynym Arcykapłanem Nowego Przymierza, dzięki czemu staje się on zdolny do reprezentowania Go w gminie i w jej imieniu. Każdy ordynowany może działać in persona Christi, zaś jego urząd jest posługiwaniem posłanego, który działa w imieniu Zbawiciela w służbie na rzecz Słowa Bożego (por. 2 Kor 3, 5). Kapłańskie święcenia uzdalniają więc do reprezentowania Kościoła przed Bogiem w sytuacji, gdy sam Kościół składa ofiarę Bogu przez Chrystusa w Duchu Świętym. Wszystkie jednak te cechy posługi duchownej urzeczywistniają się w wyjątkowy sposób w celebracji Eucharystii. Dlatego trzeba skonstatować, iż urząd z mocy święceń wprowadza Kościół w pełną i trwałą relację zależności od jego jedynego Pana ${ }^{25}$.

$24 \quad$ Dwய̈ II, n. 141 , s. 664.

25 Tamże, n. 142-142a, s. 664. Chrystus jest jedynym Pośrednikiem między Bogiem a człowiekiem, w którym pod każdym względem spełnia się kapłaństwo wszystkich czasów. W ofierze Jego życia uobecnia się cała rzeczywistość zbawienia, dlatego nowe i powtarzalne kapłaństwo Jezusa nie może być w żadnym stopniu kontynuowane ani wypełnione przez „niezależnie” działającego duchownego. Należy zauważyć, iż każde urzędowe przedsięwzięcie stanowi w pierwszym rzędzie radykalne wyzwolenie dokonane przez Odkupiciela, który powinien być wciąż uobecniany jako jedyny i wieczny Arcykapłan. Tylko wówczas urząd może osiągnąć swój cel, kiedy Chrystus będzie mógł w swobodny sposób zapoczątkować w świecie swoje panowanie. Każdy posługujący zajmuje zatem 
W katolicyzmie ośrodkiem posługiwania jest ordynowany jako następca Apostołów biskup, który we własnej osobie bądź przez swoich współpracowników - prezbiterów i diakonów - kontynuuje we wspólnocie proklamowanie apostolskiej wiary i celebrację sakramentów. Do jego obowiązków należy również troska o harmonijne (homothymadon) współżycie w obrębie gminy. Biskup reprezentuje równocześnie swój Kościół wobec innych lokalnych Kościołów w ramach uniwersalnej wspólnoty. Zobowiązani do wzajemnego utrzymywania i pogłębiania komunii wszystkich Kościołów, biskupi wraz z Biskupem Rzymu, który przewodzi powszechnej wspólnocie, tworzą „kolegium”, uznawane za kontynuację kolegium Dwunastu, pośród których Piotr występował jako pierwszy. Biskup Rzymu, uważany za następcę Piotra, jest przeto pierwszym członkiem owego gremium i posiada autorytet konieczny dla realizacji swej posługi, na rzecz jedności całego Kościoła w apostolskiej wierze i życiu ${ }^{26}$.

Należy zauważyć, iż także reformowani podkreślają znaczenie urzędu Słowa i sakramentu sprawowanego na mocy ordynacji dla życia Kościoła (por. Ef 4, 11-16). Reformowane ujęcie posługiwania jest, generalnie rzecz ujmując, bardziej „kerygmatyczne” niżeli „kapłańskie”, co koresponduje ze świadomością Słowa Bożego jako mocy, dzięki której żyje Kościół. I właśnie w tym kontekście jawi się właściwe rozumienie, iż duchowny reformowany działa w imieniu Jezusa - podczas kazania, celebracji sakramentów, w duszpasterstwie - oraz reprezentuje lud, gdy nadaje kształt nabożeństwu i mu przewodniczy. $Z$ tego więc powodu Wspólnoty reformowane przywiązują duże znaczenie do przygotowania i ordynacji duchownych, uwydatniając konieczność ustalonej struktury i nakładania rąk przez ważnie wyświęconych duchownych ${ }^{27}$.

właściwe mu miejsce, stając się wikariuszem, a nie „szefem”, co zarazem nie wyklucza istnienia gradacji pomiędzy piastunami autorytetu. Istnienie i działanie urzędu musi więc stawać się coraz bardziej wyraźne w Chrystusie, który jest jego źródłem i podstawą. Sprawujący posługę nie przemawia w oparciu o pochodzącą od niego moc, ale in persona Christi, w czym tkwi specyfika autorytetu: chodzi o pełnomocnictwo i upoważnienie do mówienia i działania w imię Pana. Dlatego więc teologiczna tradycja podaje, że sam Chrystus jest tym, który chrzci, proklamuje Słowo i celebruje Eucharystię. Por. K. Lehmann, Powierzanie urzędu w dzisiejszym Kościele, [w:] Kaptaństwo (kolekcja Communio), Poznań - Warszawa 1988, s. 343-344.

DwÜ II, n. 142b, s. 664-665.

Tamże, n. 142c, s. 665. Kościoły: rzymskokatolicki, prawosławne i anglikańskie odnajdują wierność i prawdę Kościoła zagwarantowane jedynie tam, gdzie lokalną wspólnotą kieruje biskup, znajdujący się w apostolskiej sukcesji i będący członkiem światowego kolegium biskupów (w przypadku rzymskich katolików są to wszyscy biskupi z głową owego kolegium - Biskupem Rzymu). Z kolei 
W Kościele reformowanym podkreśla się kolegialne sprawowanie episkopé. Na poziomie lokalnym odpowiedzialność spoczywa na pastorach, starszych, bądź (i) diakonach, przy czym istotną rolę często odgrywa tu kościelne zgromadzenie. Na płaszczyźnie regionalnej i krajowej jest ono sprawowane kolektywnie przez synody. Identyczny niemal mechanizm obowiązuje na forum uniwersalnym, choć trzeba zaznaczyć, że reformowani nie porzucili nadziei na zwołanie soboru powszechnego, opartego na autorytecie Biblii. Do tej pory nie udało Teologia się tego zrealizować, choć należy przyznać, iż ekumeniczne zgromadzenia światowe minionego stulecia stanowią ważny krok ku realizacji tej idei. W Kościele reformowanym istnieje również powszechne przekonanie, że XVI wiek stworzył nową formę kościelnego porządku, opartego na Piśmie Świętym i praktyce starego Kościoła, który można by zaadaptować do potrzeb nowej sytuacji. Praktycznie do chwili obecnej reformowani trwają w tej strukturze i przekonaniu, że jest ona uprawnionym i użytecznym modelem w życiu Kościoła, co jednak nie wyklucza perspektywy dalszej ewolucji w jego ekumenicznej przyszłości ${ }^{28}$.

Mimo rozpoczętych bilateralnych dyskusji i prac, struktura urzędu pozostaje nadal szczególnie trudną kwestią, choć zarazem niezbędną dla wspólnoty w Kościele powszechnym. Rozmowy odnoszące się do tego zagadnienia ukazały, jak skomplikowane są problemy w nim zawarte i jak różnorodne są zarazem perspektywy i punkty widzenia rozważane po obu stronach. Nie dziwi więc, że temat ten będzie musiał

Kościoły Reformacji tę prawdę dostrzegają w posłusznym wsłuchiwaniu się w Chrystusa, obecnego w Jego Słowie, zaś za niezbędny element struktury Kościoła uważają jedynie urząd kaznodziejski, czyli zgodne z Ewangelia zwiastowanie w Słowie i sakramencie. Wszystkie urzędy posługiwania w Kościele skupiają się wokół jednego centrum: werbalnego i sakramentalnego przekazywania Słów Jezusa. Odnosi się to bezpośrednio do protestanckiej tradycji reformowanej Jana Kalwina, który wyróżnia cztery urzędy: pasterzy (Słowo i sakrament), nauczycieli (nauka wiary), starszych (dyscyplina) i diakonów (caritas). Genewski Reformator z silnym naciskiem uwypukla nadto odpowiedzialność urzędów wspólnoty za głoszenie Słowa Bożego, ale również gminie zostaje zlecona ściśle sprecyzowana kontrola nad przemianą słowa przez wiernych w codzienne świadectwo. Por. A. Skowronek, Z Kościołem w trzecie tysiaclecie, dz. cyt., s. 79-80.

DwÜ II, n. 142de, s. 665. Trzeba zwrócić uwagę na znamienny fakt, że Kościoły protestanckie zaczyna cechować coraz bardziej powszechny kierunek ku episkopalizmowi, co przejawia się w pewnej tendencji do używania tytułu „biskup", który coraz częściej wypiera i zastępuje takie nazwy urzędu jak: prezes Kościoła, intendent czy superintendent (zwłaszcza, że dwa ostatnie terminy stanowią łacińską wersję greckiego słowa episkopos - dozorca i nadzorca). Por. A. Skowronek, Z Kościołem $w$ trzecie tysiaclecie, dz. cyt., s. 80. 
być rozwinięty w ramach nadal kontynuowanego dialogu o urzędzie kościelnym. Przede wszystkim należy zwrócić uwagę na relację między urzędem przewodniczenia, opisanym w nowotestamentalnych przekazach (przełożony, przewodnik, biskup, pasterz) i Tradycji starożytnego Kościoła, a katolickimi biskupami oraz reformowanymi urzędami Słowa i sakramentu ${ }^{29}$.

Sumując powyższe refleksje należy powiedzieć, że Kościół opiera się w swej działalności na misji Jezusa i mocy Ducha Świętego, żyjąc zaś wiarą pierwszych Apostołów zachowuje apostolski charakter. Podczas dialogowych dyskusji stwierdzono, iż powszechne kapłaństwo wszystkich ochrzczonych nie oznacza, że nie istnieją specjalne funkcje, które w ramach Kościoła spełniają przedstawiciele szczególnego urzędu, którym powierzono posługę Słowa i sakramentu. Podkreślono, że liturgiczna prawomocność aktu ordynacji przewiduje podczas nakładania rąk na wyświęcanego przez grupę ordynujących duchownych epiklezę Ducha Świętego. Katolicy i reformowani zwracali uwagę na kwestie trudne, do których należy sukcesja apostolska, choć ich poglądy odnośnie jej znaczenia pozostają rozbieżne. Uwydatniono, że fundamentalna struktura Kościoła i eklezjalny urząd posiadają kolegialny charakter, który w tradycji reformowanej znajduje swój wyraz w synodalnej organizacji, a w wyznaniu rzymskokatolickim urzeczywistnia się w kolegium biskupów. Obydwa wyznania potwierdziły także istnienie powstałej w czasach apostolskich fundamentalnej struktury urzędu biskupa, prezbitera i diakona. Katolicy i reformowani podkreślili konieczność episkopé na płaszczyźnie lokalnej, regionalnej i światowej, zauważając zarazem różnice odnośnie tego, kto na tych szczeblach może być uznany jako episkopos i na czym ma polegać jego funkcja. Zaakcentowano również doktrynę Kościoła katolickiego, według której każdy ordynowany działa in persona Christi, a jego urząd stanowi posługiwanie posłanego, który działa w imieniu Zbawcy w służbie na rzecz Słowa Bożego.

Słowa kluczowe: urząd duchowny, powszechne kapłaństwo, sukcesja apostolska, biskup, katolicy, reformowani. 